Check for updates

London

jacquiyoung1@gmail.com

Cite this as: BMJ 2020;370:m3028

http://dx.doi.org/10.1136/bmj.m3028

Published: 05 August 2020
COVID-19

\section{Leicester lockdown: could better data have prevented it?}

\section{Incomplete data and confused communication have left local officials angry and frustrated. As further local restrictions are announced, this does not bode well for future covid-19 surges, writes Jacqui Wise}

\section{Jacqui Wise freelance journalist}

Leicester was the first place in the UK to be singled out for a local lockdown in response to a spike in covid-19 cases-and some people have questioned whether it was necessary. Others certainly think it could have been handled better.

Leicester's mayor, Peter Soulsby, has accused the government of using a sledgehammer to crack a nut and says he is "incredibly frustrated" by Public Health England's inability to provide timely and detailed testing data that critics say could have helped the city avoid the lockdown.

As this article went to press, the government had just announced further local restrictions in Greater Manchester, Lancashire, and West Yorkshire in response to rising numbers of covid-19 infections. The move brought criticism for the timing and clarity of the communication, raising questions about future local lockdowns.

\section{Incomplete data}

England's health and social care secretary, Matt Hancock, first mentioned a new covid-19 "outbreak" in Leicester on 18 June during the government's daily briefing (box 1). Soulsby says this took him by surprise; he knew cases were increasing but said this was the first time anyone had used the word outbreak.

Box 1: Leicester lockdown timeline

- 15 June-PHE East Midlands first confirms an increase in cases in the city

- 18 June-Health secretary Matt Hancock announces a fresh outbreak in Leicester

- 19 June-Leicester City Council gets access to NHS digital dashboard giving more local testing data

- 25 June-The council is given postcode data after signing data security agreement

- 28 June-Home secretary Priti Patel says localised lockdowns could be used to control local flare ups

- 29 June-PHE publishes report on Leicester from rapid investigation team

- 29 June-Hancock announces the lockdown in Leicester

- 4 July-Restaurants, pubs, and other parts of the hospitality sector are allowed to open everywhere else in the country

- 16 July-Hancock announces lockdown measures to stay in place for another two weeks in Leicester city and Oadby and Wigston but to be lifted in other parts of the county from 24 July

- 1 August-Lockdown lifted in Oadby and Wigston.
The problem was that local authorities were at first only getting data from "pillar 1" of the government's national testing strategy (box 2): testing of people with a clinical need, and health and care workers. These showed that Leicester was below the average rate of new infections so did not trigger concerns.

\section{Box 2: The "pillars" of testing for covid-19}

- Pillar 1-Swab testing in Public Health England (PHE) labs and NHS hospitals for those with a clinical need, and health and care workers

- Pillar 2-Swab testing for the wider population

- Pillar 3-Serology testing to show if people have antibodies for covid-19

- Pillar 4-Blood and swab surveillance testing for research purposes

Source: Department of Health and Social Care (https://www.gov.uk/government/publications/coronavirus-covid-19-testing-data-methodology/covid-19testing-data-methodology-note)

In the first half of June Leicester's director of public health, Ivan Browne, was given access to pillar 2 community testing data, but only for people with positive test results. He asked for more complete data, but it was not until 25 June that Leicester City Council was given access to postcode data after signing a data security agreement. However, the council was given only positive results and not the total number of tests undertaken for each neighbourhood.

On 28 June the home secretary, Priti Patel, briefed that Leicester was to be subjected to a lockdown. Soulsby says this was before PHE had finished its rapid investigation report. ${ }^{1}$ He says that on the evening of 28 June the city council was sent a summary of the report, which instead of recommending a lockdown called for a delay in the relaxation measures planned for the rest of the country on $4 \mathrm{July}^{2}{ }^{2}$ This recommendation was omitted from the published version of the report, released on 29 June. Soulsby believes the decision was political. "The timing suggests it was about sending a warning to other areas," he tells The BMJ.

On 29 June Hancock announced a local lockdown in Leicester, with schools and non-essential shops closed and residents advised to stay home. ${ }^{3}$ He said the seven day infection rate in Leicester was 135 cases in every 100 ooo people, three times the rate in the next highest city, Bradford. At that time Leicester 
accounted for around $10 \%$ of all positive test results in the country over the past week, he said.

"I don't think anyone had enough data to know if a lockdown was justified,” Soulsby says. "The data we are getting is still hopelessly inadequate. We are still not getting data in a timely fashion with an address to show who has tested positive."

The Independent Scientific Advisory Group for Emergencies says that the lockdown in Leicester "constitutes a foreseeable crisis of the government's own making." " It says that the situation arose out of a failure to respond to the increase in infections at an early stage before they reached crisis levels. Kamlesh Khunti, professor of primary care diabetes and vascular medicine at the University of Leicester and a member of Independent SAGE, tells The BMJ, "We could have stopped lockdown happening if we had got the data 10 days earlier, if we had the data coming in in real time."

A Public Health England spokesperson said that the agency had been sharing all the data it had available with local authorities.

\section{Was the increase an artefact?}

Some people believe the increase in cases could be an artefact, with even PHE saying in its report, "Evidence for the scale of the outbreak is limited and may, in part, be artefactually related to growth in availability of testing." Khunti says, "The number of cases has gone up, but this has been mainly due to the increase in testing in densely packed inner city areas.”

Mike Gill, a former regional director of public health, tells The BMJ, "We know nationally there has been a huge conflation of people tested with the number of tests carried out, caused by many people having more than one test. This may lead to an inflated numerator. There is much doubt about the quality of the data, and it is possible that the government did over-react. We don't really know the true situation.”

There is no doubt that Leicester now has a very high level of testing, with 70 ooo tests carried out since 20 June. These include tests done by mobile testing units run by the army, and 500 people going door to door offering testing kits. However, when cases were rising in early June, Soulsby says, there was just one testing site, and he was calling for more testing to be carried out.

Sheila Bird, former programme leader at the MRC Biostatistics Unit at Cambridge University, doesn't believe that high levels of testing explain the increase in cases. After examining the PHE report she estimates that around 3500 pillar 1 and 2 tests were carried out in Leicester during 11-24 June, with 944 positive results (27\%). Leicester's population of 355000 means that around 3920 people would have been expected to have been tested within pillars 1 and 2, she says. ${ }^{5}$

"There does seem to have been an issue in Leicester," she tells The $B M J$. "There was a high positive rate per 100 ooo population, and that high rate of positivity does not seem to be explained by a high level of testing."

In the two weeks to 4 July a total of 10475 tests were completed, with 888 positive results, giving an $8.5 \%$ positive rate. In some inner city areas the proportion of positive tests was as high as $20 \%$. PHE's report said, "The proportion of positive PCR [polymerase chain reaction] tests as a proportion of all tests is rising and this is suggestive of a genuine increase in numbers of new infections."

Leicester City Council says that since testing has been ramped up the rate of positive results has fallen from $13.1 \%$ at the end of June to $1.9 \%$ in the week to 20 July. Soulsby acknowledges that this could be a result of more people without symptoms now being tested. "The only way you can properly understand what is happening is if you do random sampling," he says.

\section{Hospital admissions stable}

Much of the recent increase in cases has been in children and people of working age, and even though many live in multigenerational households there has been no associated increase in admissions to hospital. According to University Hospitals of Leicester NHS Trust, the number of weekly hospital admissions for covid-19 rose to a peak of 100 in early to mid-April. The number then fell to between 22 and 29 a week in late May and early June before rising to 42 in the week ending 19 June. Since then the number of admissions has generally fallen, to 18 a week on 17 July.

Khunti says, "The number of hospital admissions is stable in Leicester, and the numbers are not huge. Seventy per cent of these positive cases in pillar 2 testing are young, who are less likely to be symptomatic and more likely to have mild disease."

\section{Should the lockdown area have been smaller?}

Much of the early media coverage of Leicester's lockdown focused on the conditions in clothing factories that stayed open. However, the PHE report says there is no evidence that these were the source of outbreaks. Part of the problem is that the "occupation" field on testing forms is not compulsory, and currently only around half of tests have completed ethnicity data. Soulsby says, "Without place of work or ethnicity the data give no clue as to whether the speculation about workplace, schools, or ethnicity may have any part in the prevalence of the virus. It has been convenient to blame these factors, but the truth is that none of us know, because we haven't got the data."

More detailed postcode data provided in mid-July shows that the areas most affected were those in the inner city with high levels of deprivation, says Soulsby, who argued that continuing lockdown in the remaining $90 \%$ of the greater Leicester area was no longer justified. ${ }^{6}$

Data obtained by the Guardian showed that only $65 \%$ of close contacts of infected people in Leicester were contacted by the national track and trace system..$^{7}$ The city council has now set up its own tracing system to contact those people whom the national programme has been unable to reach.

Khunti says, “The centralised system doesn't seem to be working well in Leicester. If a middle aged, south Asian lady gets a text, it is likely she won't respond to that. You need to involve local faith groups, pharmacists, GPs, and others who have local knowledge of their populations, can speak different languages, and are culturally aware."

\section{"Constant cycle of local lockdowns"}

In the week to 17 July the number of cases in Leicester fell to 72.6 per 100 ooo population, and the city was overtaken by Blackburn as the most affected area. Some restrictions in Leicester were lifted on 24 July, by which time the number of cases had fallen to 58.6 per 100000 , and on 1 August there was further easing of the lockdown.

Independent SAGE and the BMA have called on the government to publish clear thresholds for when a lockdown or other measures (national or local) will be imposed or released. A spokesperson for the Department of Health and Social Care for England responded, "The decision on the Leicester lockdown was made using a range of health and non-health indicators. This is complex judgment, which cannot be reduced to a simple number. We must consider 
the infection rate and the test positivity rate, but also admission rates, compliance with lockdown, and the plans in place at the local level to drive down infection rates."

Independent SAGE says that the imposition of local restrictions should be considered only as part of an overall package of support and should be a temporary last resort. In Manchester, GP Siema Iqbal told The BMJ that the government's announcement was "ill timed and lacked clarity." She says, "If anything, it created more confusion."

Gill says, "With the current level of circulating virus, and in the absence of a properly functioning FTTIS [find, test, trace, isolate, support system], we are at great risk of a constant cycle of local lockdowns. We need to have a clear strategy for the future."

Competing interests: None declared.

Commissioning and peer review: Commissioned, not externally peer reviewed.

1 Rapid Investigation Team. Preliminary investigation into covid-19 exceedances in Leicester (June 2020). Public Health England. 29 June 2020 https://assets.publishing.service.gov.uk/government/uploads/system/uploads/attachment_data/file/897128/COVID-19_activity_Leicester_Finalreport_010720_v3.pdf.

2 Leicester City Council. Covid-19 in Leicester. Jul 2020. https://www.leicester.gov.uk/media/186760/leicester-in-lockdown-july-2020.pdf.

3 Hancock M. Oral statement to Parliament: plans for managing the coronavirus (covid-19) outbreak in Leicester. Department of Health and Social Care. 29 Jun 2020. https://www.gov.uk/government/speeches/local-action-to-tackle-coronavirus.

4 Independent SAGE. Statement on Leicester and local lockdowns. https://www.independentsage.org/independent-sage-statement-on-leicester-and-local-lockdowns.

5 Bird S. Leicester makes history in testing times. Significance 2020. https://www.significancemagazine.com/science/679-leicester-makes-history-in-testing-times.

6 Leicester City Council. Measuring covid-19 in Leicester. 15 Jul 2020. https://www.leicester.gov.uk/media/186767/measuring-covid-19-in-leicester-15-july-2020.pdf

$7 \quad$ Halliday J. Test and trace failing to contact thousands in England's worst-hit areas. Guardian. 22 July 2020. https://www.theguardian.com/world/2020/jul/22/test-and-trace-system-in-englandfailing-to-contact-thousands. 